\title{
The Use of Breast Cancer Survivor Patients as Part of Patient-Centred Education in the Training of Breast Cancer Care Nurses
}

\author{
Jalal E. ${ }^{a}$, Nabishah, M. ${ }^{a}$, Safiah, N.I. ${ }^{a}$, Fuad I. $^{b}$, Haslinda K. ${ }^{c}$ \& Najibah, A.R. ${ }^{d}$ \\ ${ }^{a}$ Medical Education Department, University Kabangsaan Malaysia, \\ ${ }^{\mathrm{b}}$ Oncology Department, University Kebangsaan Malaysia Medical Centre, \\ ${ }^{c}$ Nursing Department, University Kabangsaan Malaysia Medical Centre, \\ ${ }^{\mathrm{d}}$ Medical Laboratory Science Department, Faculty Biomedical and Health Science, Universiti Selangor (UNISEL).
}

\section{ABSTRACT}

INTRODUCTION: Breast cancer is the most common cancer worldwide. Patients diagnosed with breast cancer face many psychological and social distress that might affect their quality of life and indirectly might affect the disease outcome. Patient-centred education has been found to have a positive influence on the quality of management and anxiety reduction. A one-day workshop involving breast cancer survivor patients was designed as a preliminary step to improve the quality of care provided by oncology nurses in University Kebangsaan Malaysia Medical Centre (UKMMC). The objectives of the workshop were to train the nurses in providing patient-centred education using breast cancer survivor patients and to implement the breast cancer Malaysian Clinical Practice Guidelines (CPG) recommendation. MATERIALS AND METHODS: One-day workshop was designed to meet specific learning outcomes. The patient education program was introduced with special emphasis on a patient centred approach through the involvement of breast cancer survivor patients. Twenty-one staff nurses and two breast cancer survivor patients have participated in this workshop. The workshop was conducted by a breast cancer surgeon, oncologist, dietitian, family physician, and medical educators. RESULT: Overall, all participants found the workshop was very useful, particularly with the involvement of breast cancer survivor patients. Sixty - two percent of the participants agreed that the objectives of the workshop were met and $76 \%$ of them found the workshop relevant to their work. CONCLUSION: The involvement of breast cancer survivor patients in this workshop was a valuable learning experience that enhanced the patient-centred approach in medical education.

KEYWORDS: breast cancer, patient education, patient-centered care, Breast Care Nurse .

\section{INTRODUCTION}

Breast cancer is the most common cancer and the most common cause of cancer-related death in women

Corresponding Author:

Dr. Jalal Hadi

Medical Education Department,

University Kebangsaan Malaysia, Jalan Yaacob Latif

Bandar Tun Razak, 56000

Wilayah Persekutuan Kuala Lumpur, Malaysia.

Tel No: +603-91459439

Email: mahmadi1974@gmail.com worldwide. Globally breast cancer accounts for $24.2 \%$ of all female cancer cases with a higher incidence in developed compared to developing countries. ${ }^{1}$

In Malaysia, breast cancer is the most common regardless of age and gender. It accounts for $19 \%$ of all reported cancer cases and $34.1 \%$ of all female cancer cases. The incidence in Malaysia was found to be higher in Chinese followed by Indian than Malay, where the incidence was $40.7 \%, 38.1 \%$, and $31.5 \%$ respectively. ${ }^{2}$ 
The psychological and social distresses associated with breast cancer are reported in those diagnosed with the disease. This distress is related to fears of cancer, treatment-related anxiety, cancer recurrence, sexual dysfunction, and fears of death. ${ }^{3}$ Educating the patients on their disease has been identified as an indispensable element of effective treatment for cancer and chronic disease. $^{4}$ It is considered an essential part and cornerstone of patients' support. In chemotherapy, for example, the education of cancer patients before and during their course of chemotherapy has a positive influence on the quality of management and anxiety reduction. 5

The Management of breast cancer Malaysian Clinical Practice Guidelines $(\mathrm{CPG})^{6}$ has recommended that women who are newly diagnosed with breast cancer should be educated about the disease and its chemotherapy-related side effects. The CPG also recommends that all breast cancer patients should be assigned to a Breast Care Nurse (BCN) who will support the patients through the time of diagnosis and treatment journey. Psycho-educational intervention delivered by the breast care nurse to women with breast cancer during and after primary treatment was found to be effective and could provide safe passage from treatment to survivorship. ${ }^{6}$

The current practice in the provision of breast cancer care, as experienced by the staff nurses, is focused mainly on the disease, and that they perform their education process with minimal focus on patients' concerns. For reasons that breast cancer nurses need to be more patient-centred, a one-day workshop was designed to meet the following two objectives:

1. To train the nurses in providing patient-centred education through the involvement of breast cancer survivor patients to improve further the quality of care.

2. To implement the management of breast cancer Malaysian CPG recommended that the BCN be prepared to provide psycho-educational intervention to breast cancer patients.

\section{MATERIALS AND METHODS}

Twenty-one staff nurses who had the experience of nursing breast cancer patients in surgery and oncology departments and radiotherapy units as well as two breast cancer survivor patients and one simulated patient were chosen to participate in this workshop. The workshop was conducted at the oncology department at UKMMC on Saturday from $9 \mathrm{Am}$ to $5 \mathrm{Pm}$ in two sessions, morning, and afternoon. The morning sessions, that was attended mainly by staff nurses, was focussed mainly on breast cancer from surgery, oncology, and dietary perspectives through lectures and small group discussion.

The afternoon session involved activities related to patient education delivered through role-play sessions, guided reflection, and mini-lecture. The participants in the afternoon session also included breast cancer survivor patients who had different breast cancer stages and underwent different surgical approaches and different chemotherapy regimens. Their selection for this workshop was based on their oncologist recommendation. The sociodemographic characteristics of the trainees, breast cancer survivors, and simulated patients are shown in table I, II \& III.

Table IV describes succinctly how the workshop was carried out based on the three learning outcomes described below.

At the end of the one-day workshop session, the participants will be able to:

1. explain the advantages of having cancer survivor patients as part of the workshop session;

2. differentiate between disease-centred and patientcentred education approach; and

3. analyse the value of the workshop as an approach for developing an effective BCN. 
Table 1: Sociodemographic characteristic of the trainees

\begin{tabular}{lcc}
\hline Variables & Categories & $\mathbf{2 1}(\mathbf{1 0 0} \%)$ \\
\hline Age (Years) & $25-30$ & $6(28.6 \%)$ \\
& $30-35$ & $6(28.6 \%)$ \\
Gender & $35-40$ & $9(42.8 \%)$ \\
Ethnicity & Female & $20(95.2 \%)$ \\
Education level & Male & $1(4.8 \%)$ \\
& Malay & $21(100 \%)$ \\
Job specification & Other & $0(0 \%)$ \\
Duration of practice & Diploma & $10(47.7 \%)$ \\
& Post basic & $7(33.3 \%)$ \\
& Degree & $4(19.0 \%)$ \\
Nurse Manger & $2(9.5 \%)$ \\
Department & Staff nurses & $19(90.5 \%)$ \\
& 6 5 years & $5(23.8 \%)$ \\
& $>10$ years & $8(38.1 \%)$ \\
& Oncology daycare & $8(38.1 \%)$ \\
& Oncology wards & $6(28.6 \%)$ \\
& Oncology clinic & $2(9.5 \%)$ \\
& Radiotherapy unit & $2(9.5 \%)$ \\
& Surgery & $3(14.3 \%)$ \\
\hline
\end{tabular}

\section{RESULT}

Sixty-two- seventy-six percent of the participants agreed that the objectives of the workshop were met and that the workshop was relevant to their work. Almost 62\% of the participants reported that they were able to be engaged in the workshop activities. In general, they found that the lectures, group discussion, role-play, and workshop materials useful in creating a good learning environment that helped them achieve the objectives of the workshop. Overall, every participant found the workshop to be very useful and the most useful $(85.7 \%)$ is being the involvement of breast cancer survivor patients. (Table V, VI).

The involvement of breast cancer survivors in this workshop was a valuable learning experience that enhanced patient-centred education in the training program. The nurse participants found an opportunity for direct feedback on their educational strategies and ways to improve from the patients' perspective. Furthermore, the role-play with real patients provides a genuine and real-time learning experience to the participants because it provides a similar situation that
Table II: Sociodemographic characteristic of the breast cancer survivors

\begin{tabular}{lll}
\hline Variables & Categories & $\mathbf{2 ( 1 0 0 \% )}$ \\
\hline Age (Years) & $50-60$ & $2(100 \%)$ \\
Ethnicity & Malay & $1(50 \%)$ \\
& Indian & $1(50 \%)$ \\
Marital Status & Married & $1(50 \%)$ \\
& Widow & $1(50 \%)$ \\
Education & Tertiary & $2(100 \%)$ \\
Occupation & Professional & $2(100 \%)$ \\
Income & Middle income & $2(100 \%)$ \\
Stage of breast & RM1,000-5,000 & $1(50 \%)$ \\
cancer & Stage II & $1(10 \%)$ \\
Type of the surgery & Stage III & $1(50 \%)$ \\
& Mastectomy & $1(50 \%)$ \\
& Lumpectomy & $1(50 \%)$ \\
& $*$ FEC & $1(50 \%)$ \\
& $*$ AC & $2(100 \%)$ \\
& Radiotherapy & $2(100 \%)$ \\
\hline Endocrine therapy & E & \\
& &
\end{tabular}

*FEC $=5$-Flourouracil, $\mathrm{E}=$ Epirobucin, $\mathrm{C}=$ Cyclophosphamide *AC A=Adriamycin, $\mathrm{C}=$ Cyclophosphamide

they usually face in their daily practice. At the same time, the breast cancer survivor patients showed their full support and participated effectively in the role-play, discussion, and feedback sessions. They expressed appreciation for being included and allowed to be part of the group providing better care for breast cancer patients.

At the end of the workshop, the participants had mastered their communication skills to sufficiently help

Table III: Sociodemographic characteristic of the simulated patient

\begin{tabular}{ll}
\hline Variables & Categories \\
\hline Age (Years) & 38 years \\
Ethnicity & Chinese \\
Marital Status & Married \\
Education & Tertiary \\
Occupation & Professional \\
Income & Middle income RM1,000-5,000 \\
Medical history & No medical illness \\
\hline
\end{tabular}


them perform peer observation during the patient education session.

The communication skills were assessed by using an analytic rubric that consists of 5 criteria that include clarity of verbal communication, manner and poise, responsiveness, critical thinking, and overall professional attitude. Each criterion was graded to 5 levels of achievement with a total score of 25 . The main principle of using this analytic rubric during the role-play session was to provide the formative assessment for the trainees who perform the education session and at the same time, guide the peers and trainers to provide feedback and area to improve. ${ }^{7}$ Notably, in the first role-play session that was carried out before the reflective learning process, the trainees' found that their practice in educating the patients was mainly focused on patients' disease or illness with no or less attention to the patients' concerns or preference. While in the second role-play session, the trainees were able to apply the patient-centred care successfully.

Table IV: Conceptual description of the one-day workshop session on breast cancer patient education

\begin{tabular}{|c|c|c|c|c|}
\hline \multicolumn{2}{|r|}{ Morning session } & \multicolumn{3}{|c|}{ Afternoon session } \\
\hline $\begin{array}{l}\text { Teaching - Learning } \\
\text { Method }\end{array}$ & $\begin{array}{l}\text { Lecture } \\
\text { SGD }\end{array}$ & $\begin{array}{l}\text { Role-play I } \\
\text { Guided reflection SGD }\end{array}$ & Mini Lecture & $\begin{array}{l}\text { Role-play II } \\
\text { SGD } \\
\text { Guided reflection }\end{array}$ \\
\hline Theme & $\begin{array}{l}\text { breast cancer from } \\
\text { surgery, oncology, } \\
\text { and dietary } \\
\text { perspectives }\end{array}$ & $\begin{array}{l}\text { Patient education, the } \\
\text { approach used by staff } \\
\text { nurses using breast } \\
\text { cancer survivor patients } \\
\text { and simulated patient } \\
\text { (To explore the current } \\
\text { practice used by staff } \\
\text { nurses) } \\
\text { Guided reflection - } \\
\text { Focusing on } \\
\text { shortcomings and ways } \\
\text { to improve } \\
\text { (Peers and breast cancer } \\
\text { survivor patients) }\end{array}$ & $\begin{array}{l}\text { Principle of } \\
\text { patient-centred } \\
\text { education, patient } \\
\text { education aid }\end{array}$ & $\begin{array}{l}\text { Patient-centred approach } \\
\text { process using breast cancer } \\
\text { survivor and simulated patients } \\
\text { (To apply the patient-centred } \\
\text { education principles) } \\
\text { Guided reflection - Focusing on } \\
\text { shortcomings and ways to im- } \\
\text { prove } \\
\text { (Peers and breast cancer } \\
\text { survivor patients) }\end{array}$ \\
\hline Trainers / Facilitators & $\begin{array}{l}\text { Breast cancer sur- } \\
\text { geon, oncologist, } \\
\text { and dietitian }\end{array}$ & $\begin{array}{l}\text { Oncologist / Family } \\
\text { physician / Medical } \\
\text { educator/ Matron }\end{array}$ & $\begin{array}{l}\text { Medical educator } \\
\text { and Family } \\
\text { physician }\end{array}$ & $\begin{array}{l}\text { Oncologist / Family physician / } \\
\text { Medical educator/ Matron }\end{array}$ \\
\hline Participants & 21 staff nurses & \multicolumn{3}{|c|}{21 staff nurses, breast cancer survivor patients, and simulated patient } \\
\hline $\begin{array}{l}\text { Pre and post Worksho } \\
\text { (for peers and facilitat } \\
\text { Eight Principle of pati }\end{array}$ & $\begin{array}{l}\text { sessment test (fo } \\
\text { Implementation } \\
\text { entred care ( } h t t p \text {. }\end{array}$ & $\begin{array}{l}\text {, Rubric assessment tc } \\
\text { nt-centred education } \\
\text { meviewhealthcare.com/the- }\end{array}$ & $\begin{array}{l}\text { evaluate the co } \\
\text { aluated using c } \\
\text { inciples-of-patient- }\end{array}$ & $\begin{array}{l}\text { nication during role-play sessions } \\
\text { ist adopted from Picker institute } \\
\text { d-care) }\end{array}$ \\
\hline
\end{tabular}

The trainees appreciated the value and the important role of breast cancer care nurses in addressing and reducing the psychosocial distresses that breast cancer patients may have. The presence of the breast cancer survivors in this training program enriched the participated nurses with the principles of individualized patient education and patient-centred care in which, the information needed, concerns and psychosocial distresses amongst patients of the same kind of disease may vary.

Moreover, the needed information and emotional states of breast cancer patients also varied along the course of the disease. This was observed and appreciated by participants during the feedback session by breast cancer survivors.

\section{DISCUSSION}

The concept of patient-centred care refers to the high quality of care provided to the patients in healthcare settings, where the care delivery is centred on patients' needs, desires, emotions, and patients' preferences. It involves the patient and the patient's family and/or friends in the discussions and decision making related to their health problem. 8,9 Achievement of patient satisfaction, improvement of health care delivery and reduction of health care costs are reported benefits of 
this approach. Subsequently, a successful patient-centred approach in patient education would depend mainly on establishing effective communication, building partnerships with the patient, and promoting healthcare. Exploring and understanding the patient experience with the disease are key elements in establishing effective communication. ${ }^{9}$ An educational program organised for this purpose would provide the participants with a great opportunity to communicate and educate the patients using this approach as a step forward to implement it into their daily practice.

In line with patient-centred education concept, breast cancer from patients' perspective using breast cancer survivor patients became the central focus for a workshop designed to establish the Breast Care Nurse $(\mathrm{BCN})$ in UKMMC.

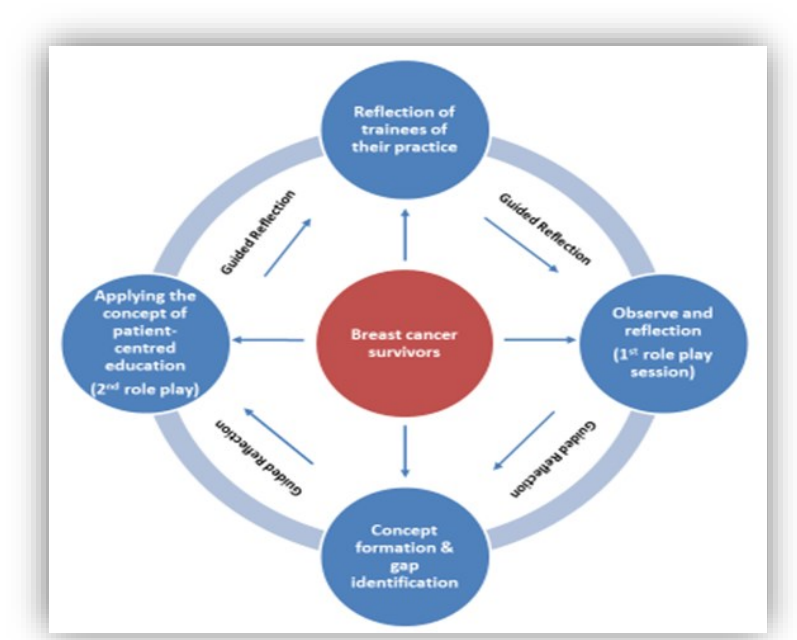

Figure 1: Reflection process of the trainees in the presence of breast cancer survivors applying David Kolb's experiential learning model (Kolb 1984).

The advantage of involvement of real patients as educational resources in this training program and its correlation with patient-centred learning and patient satisfaction was reported in previous review. ${ }^{10}$

Adult learning theory was adopted as a model of training in this workshop program. The adult learning theory is a well-known theory that is commonly used in the majority of adult training programs and health care workers. ${ }^{11,12}$ The workshop was a collaborative effort between medical education and oncology departments to provide an opportunity for the participants to reinforce their knowledge and communication skills as part of their continuing education. ${ }^{13}$
Table V: The participants' feedback of the workshop \& deliveries

\begin{tabular}{|c|c|c|c|c|c|}
\hline Items & $\begin{array}{l}\text { Very } \\
\text { useful }\end{array}$ & Useful & Fair & $\begin{array}{l}\text { Not } \\
\text { very } \\
\text { useful }\end{array}$ & $\begin{array}{l}\text { Not } \\
\text { useful } \\
\text { at all }\end{array}$ \\
\hline $\begin{array}{l}\text { How useful did } \\
\text { you find the } \\
\text { workshop? }\end{array}$ & $\begin{array}{l}21 \\
(100 \%)\end{array}$ & 0 & 0 & 0 & 0 \\
\hline $\begin{array}{l}\text { How useful did } \\
\text { you find the } \\
\text { lecture? }\end{array}$ & $\begin{array}{l}10 \\
(47.7 \%)\end{array}$ & $\begin{array}{l}11 \\
(52.3 \%)\end{array}$ & 0 & 0 & 0 \\
\hline $\begin{array}{l}\text { How useful did } \\
\text { you find the } \\
\text { group discussion? }\end{array}$ & $\begin{array}{l}8 \\
(38.1 \%)\end{array}$ & $\begin{array}{l}13 \\
(61.9 \%)\end{array}$ & 0 & 0 & 0 \\
\hline $\begin{array}{l}\text { How useful did } \\
\text { you find the role } \\
\text { play? }\end{array}$ & $\begin{array}{l}6 \\
(28.6 \%)\end{array}$ & $\begin{array}{l}15 \\
(71.4 \%)\end{array}$ & 0 & 0 & 0 \\
\hline $\begin{array}{l}\text { Your opinion } \\
\text { about workshop } \\
\text { speakers }\end{array}$ & $\begin{array}{l}6 \\
(28.6 \%)\end{array}$ & $\begin{array}{l}15 \\
(71.4 \%)\end{array}$ & 0 & 0 & 0 \\
\hline $\begin{array}{l}\text { Your opinion } \\
\text { about workshop } \\
\text { materials }\end{array}$ & $\begin{array}{l}5 \\
(23.8 \%)\end{array}$ & $\begin{array}{c}15 \\
(71.4)\end{array}$ & $\begin{array}{l}1 \\
(4.8 \%)\end{array}$ & 0 & 0 \\
\hline $\begin{array}{l}\text { How useful did } \\
\text { you find the } \\
\text { involvement of } \\
\text { breast cancer } \\
\text { survival patients } \\
\text { in this workshop? }\end{array}$ & $\begin{array}{l}18 \\
(85.7 \%)\end{array}$ & $\begin{array}{l}3 \\
(14.3 \%)\end{array}$ & 0 & 0 & 0 \\
\hline
\end{tabular}

The learning outcomes of the training program were made known to the speakers to enable them to tailor the content and level of complexity of their presentation to meet these learning outcomes. The content of the workshop, which involved many disciplines, was to refresh the knowledge of the participants about breast cancer, its principle treatment, treatment-related side effects, and dietary advice in breast cancer patients. Besides the knowledge, the communication skills of the participants were also enhanced by role-play sessions with breast cancer survivors and simulated patients. The involvement of the breast cancer survivor patients in this workshop added a beneficial learning experience to participants and provided direct feedback to the nurses about their health care delivery from the patients' perspective.

The diversity of delivery methods used in the workshop including the use of simulated patient and breast cancer survivor patients provides a comfortable learning environment that enhances nurses' engagement and participation. The active learning process where the participants put quality improvement into practice is thought to be more effective than didactic lecture alone. ${ }^{14,15,16}$ Reflection is an educational strategy that enhances the learners' knowledge and practice 17,18,19,20 
Table VI: The participants' feedback of the objectives and engagement

\begin{tabular}{|c|c|c|c|c|c|}
\hline Items & Totally & $\begin{array}{l}\text { To some } \\
\text { extent }\end{array}$ & Fairly & Poorly & $\begin{array}{l}\text { Not } \\
\text { at all }\end{array}$ \\
\hline $\begin{array}{l}\text { Were the } \\
\text { objectives } \\
\text { of the } \\
\text { workshop } \\
\text { met? }\end{array}$ & $\begin{array}{l}13 \\
(61.9 \%)\end{array}$ & $\begin{array}{l}8 \\
(38.1 \%)\end{array}$ & 0 & 0 & 0 \\
\hline $\begin{array}{l}\text { Are the } \\
\text { workshop } \\
\text { objectives } \\
\text { relevant to } \\
\text { your work? }\end{array}$ & $\begin{array}{l}16 \\
(76.2 \%)\end{array}$ & $\begin{array}{l}5 \\
(23.8 \%)\end{array}$ & 0 & 0 & 0 \\
\hline $\begin{array}{l}\text { To what } \\
\text { extent were } \\
\text { you able to } \\
\text { engage in } \\
\text { the work- } \\
\text { shop } \\
\text { activities? }\end{array}$ & $\begin{array}{l}13 \\
(61.9 \%)\end{array}$ & $\begin{array}{l}8 \\
(38.1 \%)\end{array}$ & 0 & 0 & 0 \\
\hline $\begin{array}{l}\text { Was the } \\
\text { assessment } \\
\text { relevant } \\
\text { to the } \\
\text { workshop } \\
\text { objectives? }\end{array}$ & $\begin{array}{l}11 \\
(52.3 \%)\end{array}$ & $\begin{array}{l}10 \\
(47.7 \%)\end{array}$ & 0 & 0 & 0 \\
\hline
\end{tabular}

In clinical practice, reflection is critical to provide a snap view of practice and find the means to further improve or change to an alternative practice. It has been reported that reflection is one of the critical components of professional practice in nurses' training and that the guided reflection was found to facilitate the reflective process, enhance the learning process and improve the professional practice and patient outcomes. ${ }^{21,22,23,24,25}$ In this workshop the guided reflection provided the participants with an opportunity to review their practice about patient education using Kolb's experiential learning cycle. ${ }^{26,27}$ During this experiential learning cycle, the feedback, and input from the breast cancer survivor patients were inculcated to the final concept of patientcentred education that furtherly emphasised through the key points note mini-lecture and finally practiced through the second role-play session.

\section{Limitation \& Recommendation}

The time allocated for this training program was one of the limiting factors of this study particularly the patientcentred education session that was conducted during the afternoon. Furthermore, the scenarios used for the roleplay sessions during patient-centred education were mainly related to chemotherapy, its side effects, and coping strategies to overcome these side effects. It would be more beneficial if patient-centred education cover other aspects of breast cancer care from other perspectives like surgery, radiotherapy, endocrine therapy and psychosocial distresses that are associated with breast cancer itself. However, these scenarios served as an example for the trainees to apply patientcentred education principle using breast cancer survivors.

On other hand and the bases that there was positive feedback on the workshop objectives, delivery, and engagement, a similar workshop could be recommended to train other nurses covering for breast cancer patients and other types of cancers with a special focus on patient-centred education using cancer survivor patients taking in consideration the time factor of the training and the selecting criteria of cancer survivor patients.

\section{CONCLUSION}

The collaborative work experience between the medical educators and health care providers in conducting this workshop was unique and had added many benefits in creating an interesting learning environment toward the preparation of Breast Care Nurse in UKMMC. The involvement of breast cancer survivor patients in this workshop was a valuable learning experience that enhanced the patient-centred approach in medical education.

\section{ACKNOWLEDGMENT}

The authors would like to express their acknowledgment and sincere appreciation to patients who were actively participated and gave valuable feedback during the workshop. they also would like to extend his thanks and gratitude to all speakers, facilitators, and supporting staff.

\section{REFERENCES}

1. Bray F, Ferlay J, Soerjomataram I, Siegel RL, Torre LA, Jemal A, et al. Global cancer statistics 2018: GLOBOCAN estimates of incidence and mortality worldwide for 36 cancers in 185 countries. CA Cancer J Clin 2018; 68:394-424.

2. Azizah AM, Hashimah B, Nirmal K, Siti Zubaidah AR, Puteri NA, Nabihah A, Sukumaran R, Balqis B, 
Nadia SMR, Sharifah SSS, Rahayu O, Nur Alham O, Azlina AA et al. Malaysia National Cancer Registry Report (MNCR) 2012-2016. Ministry of Health Malaysia.2019 http://nci.moh.gov.my.

3. Ganz PA. Psychological and social aspects of breast cancer. Oncology 2008; 22:642- 6.

4. Elf M, Wikblad K. Satisfaction with information and quality of life in patients undergoing chemotherapy for cancer: the role of individual differences in information preference. Cancer Nursing 2001; 24:351-6.

5. Malone PE. Implementation of a prechemotherapy educational intervention. Clin J Oncol Nurs. 2007; 11:707-10.

6. Management of breast cancer $2^{\text {nd }}$ edition, Clinical Practical Guideline 2010; 40-1. Available at: htpp:// www.moh.gov.my. Assessed February 24, 2011.

7. Shipman D, Roa, M, Hooten J, Wang ZJ et al. Using the analytic rubric as an evaluation tool in nursing education: the positive and the negative. Nurse education today, 2012; 32:246-249.

8. Gerteis M, Edgman-Levitan S, Daley J et.al. The Dimensions of patient-centred care: Treating Patients as Individuals. In: Through the Patient's Eyes: Understanding and Promoting PatientCentered Care. 1st ed. San Francisco: JosseyBass.1993: 19

9. Constand MK, MacDermid JC, Dal Bello-Haas V et.al. Scoping review of patient-centered care approaches in healthcare. BMC Health Serv Res. 2014; 14:271.

10. Bokken, L., Rethans, J.J., Scherpbier, A.J. and van der Vleuten, C.P et al. Strengths and weaknesses of simulated and real patients in the teaching of skills to medical students: a review. Simulation in Healthcare 2008; 3: 161-169.

11. Knowles MS, Holton EF, Swanson RA. The adult learner: The Definitive Classic in Adult Education and Human Resource Development. In: A theory of adult learning :Andragogy. 6th ed. California: Elsevier, 2005: 35.

12. Karayurt O, Gürsoy AA, Sultan T, Gündoğdu F. Evaluation of the breast cancer train the trainer program for nurses in Turkey. J Canc Educ 2010; 25: 324-8.

13. Patak L, Wilson-Stronks A, Costello J et.al. Improving patient-provider communication: a call to action. J Nurs Adm. 2009; 39:372-6.
14. Abbasi K, Hazrati M, Mohamadi NP et.al. The effect of learning via module versus lecture teaching methods on the knowledge and practice of oncology nurses about safety standards with cytotoxic drugs in Shiraz University of Medical Sciences. Iran J Nurs Midwifery Res. 2013; 18:4837.

15. Cheng YJ, Kao YH. Cancer nursing care education programs: the effectiveness of different teaching methods. Hu Li Za Zhi. 2012; 59:38-48.

16. Manning ML, Frisby AJ. Multimethod teaching strategies to integrate selected QSEN competencies in a Doctor of Nursing Practice distance education program. Nurs Outlook. 2011; 59:166-73.

17. Baird, J.R., Fensham, P.J., Gunstone, R.F. and White, R.T et al. The importance of reflection in improving science teaching and learning. Journal of research in Science Teaching.1991; 28: 163-182.

18. Lew, M.D., Schmidt, H.G. Self-reflection and academic performance: is there a relationship? Advances in Health Sciences Education. 2011; 16: 529.

19. Mann, K.V. Reflection's role in learning: increasing engagement and deepening participation.

Perspectives on medical education. 2016; 5: 259 261.

20. Larsen, D.P., London, D.A. \& Emke, A.R et al. Using reflection to influence practice: student perceptions of daily reflection in clinical education. Perspectives on medical education. 2016; 5: 285 291.

21. Williams B. Developing critical reflection for professional practice through problem-based learning. Journal of Advanced Nursing. 2001; 34:27 $-34$.

22. Vanlaere, L., Gastmans, C. Ethics in nursing education: learning to reflect on care practices. Nursing Ethics. 2007; 14: 758-766.

23. Asselin, M.E., Schwartz-Barcott, D. Osterman, P.A et al. Exploring reflection as a process embedded in experienced nurses' practice: a qualitative study. Journal of advanced nursing. 2013; 69: 905-914.

24. Miraglia R, Asselin ME. Reflection as an educational strategy in nursing professional development. JNDP 2015; 31:62- 72.

25. Fragkos, K. Reflective practice in healthcare education: an umbrella review. Education Sciences. 2016; 6: 27. 
26. Taylor, D.C., Hamdy, H. Adult learning theories: Implications for learning and teaching in medical education: AMEE Guide No. 83. Medical teacher. 2013; 35: e1561-e1572.

27. Sandars. 2009. "The use of reflection in medical education: AMEE Guide No. 44." Medical teacher 31: 685-695. 